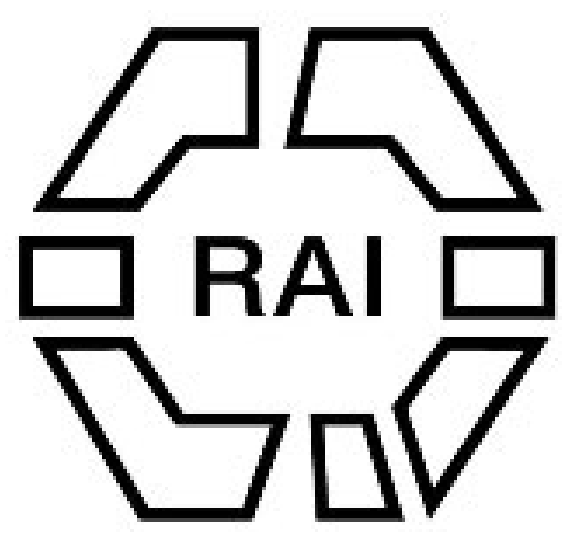

On Social Regulations in Melanesia

Author(s): R. H. Codrington

Source: The Tournal of the Anthropological Institute of Great Britain and Ireland, Vol. 18 (1889), pp. 306-313

Published by: Royal Anthropological Institute of Great Britain and Ireland

Stable URL: http://www.jstor.org/stable/2842144

Accessed: 15/06/2014 09:57

Your use of the JSTOR archive indicates your acceptance of the Terms \& Conditions of Use, available at http://www.jstor.org/page/info/about/policies/terms.jsp

JSTOR is a not-for-profit service that helps scholars, researchers, and students discover, use, and build upon a wide range of content in a trusted digital archive. We use information technology and tools to increase productivity and facilitate new forms of scholarship. For more information about JSTOR, please contact support@jstor.org. 
From the Museum.-Archæological and Ethnological Papers of the Peabody Museum. Vol. i, No. 1.

From the Socierry.-Proceedings of the Royal Geographical Society. Vol. x. No. 12.

Journal of the Society of Arts. Nos. 1880, 1881.

- Journal of the Asiatic Society of Bengal. Nos. cclxxxiii, cclxxxvi.

- Proceedings of the Asiatic Society of Bengal, 1888. Nos. 4-8.

Proceedings of the Society of Biblical Archæology. Vol. xi. Part 1.

From the Editor.-American Antiquarian. Vol. x, No. 6 .

- Nature. Nos. 996, 997.

\section{- Science. No. 303.}

- Photographic Times. No. 375.

— Revue Scientifique. Tome xlii. Nos. 22, 23.

The following paper was read by the Author:-

\section{On Social Regulations in Melanesia.}

By the Rev. R. H. CodRIngton, D.D.

IT is necessary, in the first place, in speaking of Social Regulations in Melanesia to say, that my observations are limited to the Northern New Hebrides, the Banks' Islands, the Santa Cruz Group, and the South-eastern Solomon Islands. My knowledge of the social condition of the people in these groups has been derived partly from what I have observed myself, and very much from careful enquiry I have' made from natives well qualified to give information. A considerable portion of the Melanesian field is thus in view, and in this there appears to be a general agreement in social arrangements : it may therefore be inferred that there is a wider likeness throughout the region occupied by the Melanesian people.

I propose to deal only with the two subjects of (I.) Marriage, and (II.) Property.

\section{Social Regulations relating to Marriage.}

The arrangement of society depends on the division of the whole population into two or more classes, which are exogamous, and in which descent is counted through the mother. With one remarkable exception, this division obtains in every settlement, large and small; and it is the knowledge of this that forms probably the first social conception in the mind of the young Melanesian. It stands foremost in the native view of mankind, and is the foundation on which the fabric of society is built up. To the Melanesian man it may be almost said that all women, of 
his own generation at least, are either sisters or wives-to the Melanesian woman that all men are brothers or husbands.

An excellent illustration of this is given in a story from Aurora in the New Hebrides, in which Qatu discovers twin boys, children of his dead sister, and brings them to his wife. "Are these," she asks, " my children or my husbands ?" Qatu answers, "Your husbands to be sure ; they are my sister's children."

I cannot call these divisions "tribes"; the members of them are all intermixed in habitation and in property, and are equally subordinate to the chief of the place in which they dwell; the perfectly well understood and acknowledged relationship through the father connects those who through their mothers are not of kin.

Examples of these divisions may be taken from two regions: (a) where there are two, as in the Banks' Islands and Northern New Hebrides ; $(b)$ where there are more than two, as in Florida in the Solomon Islands.

(a) 1. The same two divisions run through the Banks' Islands and the Northern New Hebrides without a name; every one knows who are his kin. In the Banks' Islands the common term is veve, a word conveying the notion of distinction; in Lepers' Island, in the New Hebrides, there are two waivung, bunches of fruit. Neither veve nor uaivung has a distinguishing name.

2. Each division is strictly exogamous; every member of either must marry into the other. Irregular intercourse between members of the same division is a heinous offence; should such become known the members of the other division will destroy the property of the one in which the guilt is found, without resistance or complaint.

A general term, in Mota qaliga, embraces all of the opposite division who have been brought near by marriage, fathers-, mothers-, brothers-, sisters,-in-law. Towards all of these there is a certain degree of reserve; some, particularly mothers-in-law, are avoided. This reserve, which the natives themselves ascribe to a feeling of shyness or respect, is exercised by a man not only to those who are of his wife's kin such as her mother, but also to those who are not of his wife's kin, such as her father. There is in this matter of avoidance and reserve a good deal of diversity in the practice of different islands; in Lepers Island the intercourse of mother and son, and of brother and sister, is closely restricted. In the Banks' Islands one cannot use a word which is the name, or part of the name, of a qaliga; and there is a set of words kept in use to take the place of those which may commonly cause a difficulty of this kind.

As this name of qaliga applies to both sexes alike, so this reserve and avoidance of the person and name is practised by men and women. 
3. It must not be thought that the male and female members of the two divisions are in fact husbands and wives ; there is no occasion on which the wives of the men of one division become common to all the men of that division. There does not appear to be any tradition that communal marriage erer existed. The story of Qat in the Banks' Islands shows individual marriage in the case of the first-made woman, whom Qat wove for himself with pliant rods and brought to life for his own wife, and whom Qat's brothers tried in vain to carry off from him for themselves. Yet there is a certain consciousness of the meaning of the words they use for husband and wife and mother.

In Mota the word used for mother, is the same that is used for the division, veve, with a plural sign ra veve. And it is not that a man's kindred are so called after his mother, but that his mother is called his kindred, as if she were the representative of the division to which he belongs; as if he were not the child of a particular woman, but of the whole kindred for whom she has brought him into the world.

In the same way at Mota, the word for consort, husband or wife, is in a plural form, ra soai, the word used for members of a body or the component parts of a house or canoe. So that it is not the man and his wife, or wives, that make up a compound whole, but all the men on one side and all the women on the other; and the wife or husband has the plural designation, because the individual man or woman represents all the rest who are in the position to be wives or husbands.

The Levirate obtains as a matter of course, so far as that a woman who has become the widow. of one member of a family connexion remains as the wife of another member of the same. A wife is obtained by a certain payment, towards which the near relations of the bridegroom, both on the father's and mother's side, contribute; it is arranged, therefore, in case of death to which member of the family connexion it will be most convenient and economical that the widow should pass, whether brother, uncle, or cousin of the deceased, of course of his own kin. In the same way an uncle on the mother's side will set up his sister's son, his nearest of kin, in life, by making over to him one of his own wives. Not that the young man had a right to his uncle's wives ; but the woman was already in the family.

4. The closest relationship is that between the sister's son and mother's brother. This follows on the descent through the mother: the child is not of kin to his father or to his father's brothers and sisters; his mother's brother stands to him as the male representative of. his kindred. At the same time all the father's brothers are called fathers, and the father's sisters mothers ; in fact, all on both sides who are near the father's and 
mother's generation are called fathers and mothers, except the maternal uncles, who alone have a distinctive name. If a pedigree is drawn up, it will be found that the son takes his mother's place in it; that is to say, if $\mathrm{A}$ and $a$ are brother and sister, the grandson of $a$ counts as of the same generation with the son of A.

In the Banks' Islands the sister's son, vanangoi, has certain rights with his maternal uncle, maraui, corresponding to those of the Fiji vasu, but by no means conspicuous or important. It is a matter of course that the nephew should look to his uncle for help of every kind, and that the uncle should look upon the nephew as his special care. The closeness of this relation is fundamental.

It must be understood withal that the mother is in no way the head of the family; the family house is the father's, the garden is his, the rule and government is his. It is into the father's house that the young bridegroom takes his wife, if he has not one ready of his own.

5. There is in these islands a certain practice of couvade; that is, the father before and after the child's birth refrains from certain food and violent exertion which might damage the infant; but the practice of this is not conspicuous. It is considered kind and respectful to call a man when he has a child the father of so and so; his station in society is advanced by his paternity, and it is recognised in this way.

6. I can point to nothing which appears to me to represent capture in marriage, nor do the circumstances admit of such a kind of exogamy. The two intermarrying divisions live in each settlement intermixed; the inhabitants of any island or village, and any enemies they may have, are composed of the same two divisions. There is in no case war of tribe against tribe, but of village against village, or set against set; if only two families are at enmity both divisions must be represented in each.

Adoption cannot be thought of any inportance; orphans are taken by near relations or childless people, or parents will give up a child to friends who wish to have it, generally in the same division.

(b) Florida, and the parts of the Solomon Islands near to it, afford the example of a district in which the marriage divisions are more than two. It is probable that the four or six found there are subdivisions of the original two. In Florida these divisions are six, and are called kema, a word the meaning of which I cannot explain. In strict exogamy, in descent following the mother, and intermixture of dwelling and property, all is the same as in the Banks' Islands. There are two points in which important differences must be observed.

1. Each division, kema, has its distinguishing name. Two of 
these names are local, pointing to neighbouring islands; two are names of living creatures. It is evident that the use of names is almost a necessity to prevent confusion where many men have wives, and therefore children, of three or four different kema. Since all the children own the common father, the patriarchal element would soon prevail if clear distinction were not made.

2. It adds much to the distinction between the divisions that each has some one thing, or more, from which its members must most rigidly abstain, its buto, something that must not be eaten. The impression is deep and abiding on the mind of every child that to eat the forbidden food of its kema is a dreadful thing.

There occurs, therefore, the question whether there is not in this something of a totem. But one division, the Manukama, has its name from a bird, the osprey, and is at liberty to eat that bird, while it is forbidden to eat the pigeon.

A member of one of these divisions will probably say in answer to a question that the thing he cannot eat represents the original ancestor of his kema; one of the osprey division will say that his ancestor was a pigeon. The explanation of this appears to me to be found in a practice of the people of Ulawa, another of the Solomon Islands. Some of them will not eat bananas, and of late had ceased to plant any; the banana is to them what in Florida would be their forbidden food. But the origin of this restraint in Ulawa is recent and remembered; a man of much influence not long ago forbad the eating of the banana after his death, saying that the banana should represent him, that he would be in the banana. In doing this he did what is not unconmon in the neighbouring part of Malanta. In Florida, therefore, the prohibition may be taken to be of the same kind. In Bugotu, part of Ysabel, I am assured that such prohibitions have only been lately introduced.

The practice at Ulawa is illustrated by what is common at Saa, in Malanta. A man before his death will say that after he dies he will be a shark. When he is dead the people will look out for the appearance of some remarkable shark and pronounce it to be he. Certain food, cocoanuts for example, will be reserved to feed this shark. Then it often happens that a man professes to be possessed by the ghost of this man, who has reappeared as a shark, and speaking as with the voice of the dead man, he will claim the privilege of eating the food reserved for the shark. Such a person will then take his place with others who have before made the same demand; and at his death again he will be thought to become, or his ghost to inhabit, a shark. Under such circumstances, it will be freely asserted that an ancestor was a shark.

In the island of Aurora, Maewo, in the New Hebrides, women sometimes have a notion that the origin, beginning, of one of 
their children is a cocoanut or a bread-fruit, or something of that kind; and they believe, therefore, that it would be injurious to the child to eat that food. It is a fancy of the woman before the birth of the child that the infant will be the nunu, which may be translated the echo, of such an object. Women also fancy that a child is the nunu of some dead person. It is not a notion of metempsychosis, as if the soul of the dead person returned in the new born child; but it is thought that there is so close a connection that the infant takes the place of the deceased. At Mota, also in the Banks' Islands, there was the belief that each person had a source of his being, his origin, in some animate or inanimate thing, which might under some circumstances become known to him.

It is possible that these fancies may serve to explain to some extent the origin of the totem.

3. A remarkable exception to the prevailing exogamous division of the Melanesian people remains to be noticed. In the south-eastern part of the Solomon Islands, in Malanta, Ulawa, and San Cristoval, these divisions are, as far as I know, altogether absent; and, moreover, descent is counted through the father, not through the mother. I cannot account for this, and do not know whether the matriarchal system does not prevail in other parts of the same islands, with which I am not acquainted. The most conspicuous example of the couvade within my knowledge among Melanesians, was shown in this same region where descent follows on the father's side.

\section{Property.}

1. Land is everywhere divided into (1) the Town, (2) the Gardens, (3) the Bush. Of these the two first are held as property, the third is unappropriated.

2. Land is not held in common; every one knows what belongs to himself. Yet the individual has the possession only of what he has inherited, and uses for his life-time as part of the whole property which belongs to the family. There are not two or more divisions of the land thus held in property corresponding to the marriage divisions of the people; the land of these divisions is intermixed. Probably in the origin of each settlement the members of each marriage division worked together; as it is, families have formed themselves within the marriage divisions, and the land is in the possession of families. The chiefs have nowhere more property in the land or more right over it than other men; though, naturally, they are willing to assert such claims in selling to Europeans, and often use their power to drive away the owners of gardens they $\mathrm{d}$ ssire to occupy. Before the coming of Europeans, the sale of land was not unknown, though certainly not common; of late, especially in the 
New Hebrides, much land has been nominally bought from chiefs, or supposed chiefs, but by no true sale. There is a remarkable example of the fixedness of native right of property in land to be seen at Saa in the Solomon Islands, at the southernmost part of Malanta. The much greater and much more important number of the inhabitants are descendants of refugees, who came, eleven generations ago, from inland, and were received by the then owners of the place, who allowed them the use of land for houses and gardens. To the present day, with the exception of some parcels they have bought, or which have been given to them, these immigrants, even powerful chiefs, have no land of their own; it is perfectly understood that the land they occupy belongs to the original inhabitants. But, in fact, everywhere, or almost everywhere, the abundance of land makes it of little value.

3. If an individual reclaims for himself a piece of bush land, it becomes his own; and the different character of his property in it is shown by the difference in the right of succession to it. If, as sometimes happens, a village grows up in the garden ground of an individual, or of a family, the property in the house sites is recognised as not being altogether that of the occupiers. They pay no rent, but they show a certain respect and consideration for the representative of the proprietor.

4. It is remarkable that fruit trees planted, with the consent or acquiescence of the owner, upon another man's land, remain the property of the planter and of his heirs. In a true sale, the minute and accurate knowledge of property in land and trees is remarkably displayed. I once completed the purchase of a site for a mission school in the Banks' Islands, and found the rights, and the limits and value of the rights, of every man and woman concerned surprisingly acknowledged and defined by common consent. When I thought all was finished, a fresh applicant for payment on account of a fruit tree appeared from a distance, accompanied by the owner of the land on which the tree grew, who testified that the claim was good. "Certainly," he said, " the claimant's grandfather had planted that tree, and he had the right to it."

5. Personal property consists in pigs, which are everywhere much valued; money, in whatever form it is found, canoes, ornaments, weapons, and the various implements used in native life.

6. Succession to property of all kinds is regularly and properly with the sister's son, or with others who are nearest of kin to the deceased through his mother. If the owner has not made testamentary arrangements before his death, his heirs divide his personal property amongst themselves, according to their opportunity rather than their right. A man before his death will make arrangements by which his sons may receive a part at 
least of his land; or the sons after his death will redeem it from their father's kin. In doing this, they will sometimes lay the redemption money on their father's corpse, from which his proper heirs will take it publicly, so that there shall be no dispute.

Whatever property, however, a man has acquired for himself, as when he reclaims a piece of land from the bush, he may leave to his sons; or his sons, and their sons after them, may claim. This is the source of many quarrels, the character of a piece of ground being forgotten in course of time, or disputed by the regular heirs to the rest of the land. It is evident that much of a man's personal property is the direct produce of his own industry, and will so seem to be the natural inheritance of his own children. A man will, if he can, arrange before his death that his sons shall have it; or his sons after his death will redeem it if they can from their father's kin. But a man's kindred on the mother's side will always maintain their position as the natural and proper heirs of whatever he possesses.

It thus appears that there is a tendency to the succession to property by a man's own children, and a practical relaxation of the law by which a man's heirs were his kindred by the mother. This has followed to some extent on the occupation of new ground, and may, therefore, be thought to have been strengthened by the formation of new settlements. But it is evident that such a tendency is founded on the assertion of paternity; and the existence of such a tendency may be taken to mark a transition from the matriarchal to the patriarchal system.

\section{Discussion.}

Dr. E. B. TYLOR, expressing his sense of the important bearing of the paper on the principles of systems of social structure, called particular attention to the clearness with which a system of exogamy is exemplified, which is not only the simplest possible, but is probably also the most primitive. This dual division of society for the purpose of intermarriage apparently accounts for the fact that among other peoples totemic division is most often into two halves, these being again sub-divided. It is also from the dual division that the most important system of classificatory relationship is apparently devoid, as has been shown by Mr. Fison. Dr. Codrington remarks on the manner in which a particular vegetable or animal may be brought, through a rule of abstinence, into connexion with a particular ancestor. It is possible that the tribes who talk of themselves as descended from a dog or a corn-plant, may have had underlying this paradox a meaning more rational from our point of view, and the facts now brought forward show at any rate a custom actually going on, which, in a natural way, leads men to formulate a statement leading (when taken verbally) to such belief. Enquiry would have to be made how far similar commemoration by abstinence, and consequent choice of a totem, prevails among tribes elsewhere in the world. 